\title{
Derleme
}

Mersin Üniv Saglık Bilim Derg 2019;12(2):351-359

doi: 10.26559/mersinsbd.517921

\section{Deneysel şizofreni modellerinin oluşturulması ve deneysel yöntemlerle şizofreni belirtilerinin değerlendirilmesi}

\author{
Tuba Özkul ${ }^{1}$, Asuman Gölgeli ${ }^{2}$ \\ ${ }^{1}$ Erciyes Üniversitesi, Halil Bayraktar Sağlık Hizmetleri Meslek Yüksek Okulu, Kayseri, Türkiye \\ ${ }^{2}$ Erciyes Üniversitesi Tıp Fakültesi, Fizyoloji Anabilim Dalı, Kayseri, Türkiye
}

Öz

Yaygın ve ciddi bir psikiyatrik hastalık olan şizofreni, dünya nüfusunun \%0.5-\%1'ini etkilemektedir. Şizofreni çeşitli semptomlarla seyretmesi nedeniyle kompleks klinik bulguları olan nörogelişimsel bir bozukluktur. Etiyolojisi tam olarak bilinemeyen şizofrenin gelişiminde beyindeki kimyasalların, yapısal farklılıkların ve genlerin etkisi olduğu düşünülürken; patogenezinde çevresel, psikolojik ve sosyal etkenlerin rolü olduğu düşünülmektedir. Deneysel hayvan modellerinin geliştirilmesi, insanlarda modellenemeyen bu hastalığın fizyopatolojisini ve nörobiyolojik temellerinin anlaşılmasına imkân sağlamaktadır. Deneysel yöntem olarak kalsineurin, neuregulin gibi genler genetik modellerde; prenatal stres gelişimsel modellerde; dopaminerjik agonist gibi ilaçlar ilaç ve kimyasal modellerde; hipokampal lezyon neonatal hipokampüs lezyon modellerinde deneysel hayvan modelleri oluşturulmasında kullanılmaktadır. Düşük enerji, motivasyon eksikliği, delüzyon, halüsinasyon, anlamada ve öğrenmede yetersizlik, bellekte zayıflama vb. şizofreninin bilinen semptomlarındandır. Değișik yöntemlerle oluşturulan deneysel hayvan modellerinde hangi semptomun ortaya çıktığını belirlemek için davranıșsal test yöntemleri kullanılmaktadır. Bu test yöntemlerinden prepulse inhibisyon ve yeni obje tanıma testleri çoğunlukla kullanılmaktadır. Yeni obje tanıma testi şizofreninin kognitif semptomlarıyla, prepulse inhibisyon testi ise pozitif semptomlarıla ilgilidir. Genetik, gelişimsel ve kimyasal modellerle oluşturulan bu hastalığın temellerini kavrayabilmek ve yeni tedaviler geliştirebilmek için deney hayvanı modellerinin geliştirilmesi ve daha geniş çaplı çalışmalarda kullanılması gerektiği sonucuna varılmıștır.

Anahtar Kelimeler: Bellek, deneysel hayvan modelleri, fizyopatoloji, genetik, şizofreni

\section{Development of experimental schizophrenia models and evaluation of schizophrenia symptoms with tests}

\footnotetext{
Abstract

Schizophrenia, a common and serious psychiatric disorder, affects $0.5 \%$ to $1 \%$ of the world population. Schizophrenia is a neurodevelopmental disorder with complex clinical findings due to various symptoms.

Yazının geliş tarihi:25.01.2019

Yazının kabul tarihi:24.06.2019

Sorumlu yazar: Öğr. Gör. Tuba Özkul Erciyes Üniversitesi Halil Bayraktar Sağlık Hizmetleri MYO 38039 Kayseri, Türkiye. Tlf:03522076666/40008, e-posta: tubaozkul@erciyes.edu.tr
} 
While the etiology of schizophrenia is unknown, it is thought that chemicals in the brain, structural differences and genes have effects on the disease; environmental, psychological and social factors are thought to play a role in the pathogenesis. The development of experimental animal models allows for better understanding of the physiopathology and neurobiological bases of this disease which cannot be modeled in humans. As different experimental methods, genes such as calcineurin and neuregulin in genetic models; prenatal stress in developmental models; drugs such as dopaminergic agonist in pharmaceutical and chemical models; hippocampal lesion is used in the production of experimental animal models. Low energy, lack of motivation, delusion, hallucinations, inability to understand and learning, memory attenuation etc. are known as symptoms of schizophrenia. In experimental animal models produced by different methods, behavioral test models are used to determine which symptoms occur. Among these test methods, prepulse inhibition and new object recognition tests are mostly used. The new object recognition test is related to the cognitive symptoms of schizophrenia while the prepulse inhibition test is related to its positive symptoms. In order to understand the basics of this disease, which is formed by genetic, developmental and chemical models, and to develop new treatments, we reached a conclusion that more advanced experimental animal models should be developed and used in more comprehensive studies.

Keywords: Memory, experimental animal models, physiopathology, genetic, schizophrenia

\section{Giriş}

Mental fonksiyonlarda, duygulanımda ve davranışlarda bozulma ile karakterize olan şizofreni popülasyonun yaklaşık \%1'ini etkilemektedir.1,2 Dünya sağlık örgütünün 2016 verilerine göre, her toplumda ve her türlü sosyoekonomik sınıfta görülen şizofreni hastalarının sayısının dünyada 21 milyondan fazla olduğu, Türkiye de ise yaklaşık 500 bine ulaştığı açıklanmıştır. ${ }^{3}$

Negatif, pozitif ve kognitif semptomlarla seyreden şizofreni, en sik rastlanan ve iyi bilinen psikotik hastalıkların başında gelmektedir. ${ }^{4}$ Yapılan çalışmalarda bu üç ana semptomun farklı göstergelerine vurgu yapılmaktadır. Negatif belirtiler; düşük enerji, motivasyon eksikliği gibi belirli normal davranışların eksikliğini yansıtmaktadır. Pozitif belirtiler; delüzyon ve halüsinasyonları içermektedir. ${ }^{5}$ Bilișsel (kognitif) fonksiyonlarda ise; bellekte zayıflama, anlamada ve öğrenmede yetersizlikler șeklinde bozulmalar olduğu ifade edilmektedir. Dış uyaranların taranması, inhibe edilmesi, filtrelenme ya da kapılmasında yetersizlik, diş ve iç uyaranlar tarafından aşırı yüklenmeye yol açarak, şizofreni hastalarının bilişsel bütünlüklerinin bozulmasına neden olmaktadır. ${ }^{6}$
Sanrı ve varsanılar gibi davranışsal bozukluklarını belirlemekteki güçlüklerden dolayı $^{7}$ şizofreni tüm psikiyatrik bozuklukların modellenmesinde en zorları arasında bulunmaktadır. Diğer yandan, insanlarda deneysel çalışmaların sınırlılığı, şizofreninin yeni terapötiklerini belirleme çabasında bizi geçerli hayvan modellerine yöneltmektedir.8 Günümüze kadar oluşturulmuş deney hayvanı modelleri çalışmalarına bakıldığında şizofreni dört şekilde olușturulabilmektedir. Bunlar, genetik modeller, gelişimsel modeller, ilaç veya kimyasal maddeler ile oluşturulan modeller ve lezyon modelleridir. Oluşturulan deneysel modellerde hangi belirtilerin başarılı bir şekilde modellendiği deney hayvanlarında yapılan bazı ölçüm yöntemleri ile ortaya konulabilmektedir. ${ }^{4}$ Örneğin prepulse inhibisyon (PPI-ön uyaran aracılı inhibisyon) ve yeni obje tanıma gibi bazı deneysel testler hem şizofreni hastalığının etiyolojisinin araştırılmasında hem de yeni ilaç geliştirilmesi açısından en çok kullanılan yöntemlerdendir.

$\mathrm{Bu}$ derleme şizofreni hastalı̆̆ında deneysel olarak kullanılan hayvan modelleri ve belirtilerin ölçümünde kullanılan deneysel test yöntemleri olan ön uyaran aracılı inhibisyon ve yeni obje tanıma hakkında bilgi sunmayı amaçlamaktadır. 


\section{1. Şizofreni modeli oluşturmak için kullanılan yöntemler}

1.1. Genetik Modeller: Şizofreni riskinin artmasında büyük bir gen dizisinin ilişkili olduğu bulunmuştur. Genetik modellerin çoğu şizofrenide görülen protein ve mRNA'daki değişiklikleri göstermektedir. ${ }^{4}$ Şizofrenide rol oynayan riskli genler, genetik model çalışmalarından elde edilen sonuçlara dayanılarak tartışılmıştır. $\mathrm{Bu}$ genlerden reelin, neuregulin ve kalsineurin genel olarak sinaptik plastisitede, DISC-1 ve disbindin ise nörogenezde rol oynamaktadır.

Reelin: Reelinin sinaptik fonksiyonu ve özellikle sinaptik plastisiteyi düzenlediği bilinmektedir. Şizofreni gelişiminde yer alan moleküler adaylar arasında ${ }^{9}$, reelin prenatal stres ile şizofrenide görülen hücresel ve fizyolojik değişiklikler arasında önemli bir bağlantı gibi gözükmektedir. ${ }^{10}$

Kalsineurin: Sinaptik iletim ve plastisite dahil olmak üzere bir dizi nöronal süreci düzenleyen ${ }^{11}$ ve merkezi sinir sisteminde önemli rol oynayan kalsineurin, kalsiyum ve kalmodulin bağıml protein fosfatazdır. Kalsineurin fonksiyonunda meydana gelen değişikliklerin şizofreni patogenezinde önemli bir faktör olduğu düşünülmektedir. ${ }^{12}$

Neuregulin: Neuregulin proteini ve reseptörlerinin etkileşimiyle N-Metil-DAspartat (NMDA) reseptörünü düzenleyerek glutamaterjik sinyallemeye katılır. Neuregulin sinyalinin eksikliği bazı şizofreni vakalarıyla ilişskili olabilir. ${ }^{13}$

DISC-1: DISC-1 geni, şizofrenide rolü olduğu bilinen ilk gendir. DISC-1 ekspresyonundaki düzensizlik ya da protein yapısında meydana gelen değişimler nörogenezde eksiğe yol açtığı ve şizofreniye neden olduğu düşünülmektedir. ${ }^{14}$

Disbindin: Son yıllarda disbindin (DTNBP1) geni, şizofreni için en umut verici aday genlerden biri olarak ortaya çıkmıştır. Şizofreni teşhisi yeni konmuş hastalarda bu genin mutasyonları ve hastalık arasında güçlü bir ilişki olduğu gösterilmiştir. ${ }^{15}$ Ayrıca, şizofreni hastalarında hipokampüs ve prefrontal kortekste azalmış disbindin geni ve protein ekspresyonu bildirilmiştir. ${ }^{16-17}$
1.2. Gelişimsel modeller: Şizofreninin intrauterin hayatta iken temellerinin atılmaya başlandığı ve bu hastalığın aslında gelişimsel bir hastalık olabileceği son yıllarda yapılan çalışmalardan elde edilmiştir. Bugüne kadar bu teoriyi destekler pek çok veriye ulaşılmıştır.18

Prenatal stress: Prenatal stres, şizofreni de dahil olmak üzere birçok nörogelişimsel bozukluk için bir risk faktörü olarak düşünülür. ${ }^{19} \mathrm{Bu}$ sıçanların sosyal etkileşimlerinin azaldığı, prepulse inhibisyon değerlerinin düşük olduğu, anksiyete seviyelerinin yüksek olduğu, hipokampüste meydana gelen değişiklikler nedeniyle öğrenme ve hafıza bozukluklarının gözlemlendiği tespit edilmiştir. $\mathrm{Bu}$ bozuklukların temel nedeni olarak beyinin gelişimi sırasında stres hormonlarına duyarlı olması ve beyindeki nörotransmitter sistemleri etkilemesi gösterilmektedir. ${ }^{4}$

Prenatal immun aktivasyon: Kızamıkçık, influenza ve toksoplazma şizofreni ile ilişkili doğum öncesi enfeksiyonlar arasındadır. İnterlökin-8 içeren maternal sitokinler, gebelikteki şizofren vakalarını önemli ölçüde artırmaktadır. ${ }^{20}$

1.3. İlaç ve kimyasal modeller: Çeşitli nörotransmitterler üzerinden meydana gelen değişiklikler açısından oluşturulan deneysel hayvan modelleri farmakolojik model olarak da adlandırılır. Yapılan çalışmalarda seratonerjik, dopaminerjik ve glutamaterjik sistemler şizofreni ile ilişkilendirilen ana nörotransmitter sistemlerdir. Ayrıca, son yıllarda kolinerjik sistemin de özellikle bilişsel belirtiler ile ilişkisi yaygın olarak ortaya konmuştur. ${ }^{4}$

NMDA reseptör antagonistleri: Yapılan çalışmalarda, glutaminerjik sistemde NMDA reseptörlerinin hipofonksiyonu ile şizofreninin pozitif semptomları bağdaştırılmaktadır. ${ }^{21}$ NMDA-glutamat reseptör antagonisti olan ketamin, fensiklidin, amfetamin gibi ajanların kişilerde şizofreni belirtilerine benzer psikoz tablolarını ortaya çıkardığı ve zaten şizofreni olan kişilerde de hastalık belirtilerini 
artırdığ 1 gözlenmiştir. ${ }^{22}$ Diğer yandan glutamatın dopamin ile olan ilişkisinin de şizofrenide etkisi olduğu düşünülmektedir. ${ }^{23}$

Dopaminerjik agonistler: Şizofreni ile ilgili olan nörotransmitterlerin başında dopamin gelmektedir. Şizofreni-dopamin hipotezi dopaminerjik sistemdeki dopamin dengesizliği ile ilişkilendirilmektedir. Amfetamin uygulamasiyla oluşturulan dopamin hipotezine dayalı deneysel hayvan modeli, farmakolojik modeller arasında en iyi model olarak nitelendirilebilir. ${ }^{24}$ Deneysel hayvan modellerinde kullanilan amfetaminin PPI testinde bozucu etkisi yapılan çalışmalarda ortaya çıkmıştır. ${ }^{25}$ Dopamin agonisti olan apomorfinin sıçanlarda kullanılması sonucu PPI' da şizofreni hastası olan insanlardakine benzer şekilde bozulmalar meydana getirmiștir. ${ }^{26}$ Ayrıca antipsikotik ilaç tedavisi ile apomorfinin PPI üzerinde meydana getirmiş olduğu bu bozucu etki geri döndürülebilmektedir. ${ }^{27}$

Serotonin agonistleri: Şizofrenide rol aldığı bilinen serotonin hipotezinin ortaya çıması 1950'li yıllara dayanmaktadır. Ortaya atılan bu hipotez, bir halüsinojen olan liserjik asid dietil esterinin (LSD) serotonin aracılığıyla etki göstermesine dayanır. ${ }^{28}$ Dopaminerjik hayvan modelinde olduğu gibi LSD verilen hayvanlarda ve insanlarda PPI bozulmaktadır.4

Kolinerjik antagonistler: Muskarinik antikolinerjik ajanlardan atropinin klinikte yaygın kullanımı sırasında gözlemlenen tablolardan biri olan antikolinerjik sendrom bulguları psikoz tablosuna çok benzemektedir. Hastalarda işitsel ve görsel halisünasyonlar ve amnezi gerçekleşmektedir. $\mathrm{Bu}$ bulgulardan yola çlkarak bir diğer antikolinerjik ajan olan skolpolamin ile deney hayvanlarında psikoz benzeri tablo olușturarak şizofreninin özellikle pozitif ve bilişsel semptomları modellenebilmektedir. ${ }^{29}$

\subsection{Neonatal Hipokampüs lezyonu: En yaygın} kullanılan lezyon modeli neonatal ventral hipokampal lezyon modelidir. Bu modelin başlıca avantajlarından biri şizofreni hastalarında gecikmeli olarak ortaya çıkan semptomların başlangıcını gösterebilme yeteneğidir. Dorsal hipokampüs ve ventral hipokampüsteki egzositotoksik lezyonlar farklı davranışsal profiller göstermektedir. Yeni doğan ventral hipokampüs lezyonlu sıçanlarda nükleus akkümbenste dopamin ve metabolitlerinin değişimi gösterilmiştir. Ayrıca bu sıçanlarda şizofreninin negatif semptomlarından olan sosyal etkileşim eksikliği ve agresif davranışlarda artış olduğu gösterilmiştir. ${ }^{30}$ Oluşturulan lezyonların ergenlik öncesi dönemde gerçekleştiği göz önüne alındığında bu model şizofreninin nörogelişimsel modeli olarak kabul edilmektedir.

\section{Sizofreni modellerinde davranıssal ve bilişsel fonksiyonların ölçülmesi}

Yukarıdaki yöntemlerle oluşturulan şizofreni modellerinde, şizofreninin pozitif, negatif ve kognitif belirtilerini ölçmek için çeşitli deneysel testler kullanılmaktadır. Pozitif belirtilerde PPI testi, bilișsel belirtilerde ise yeni obje tanıma testi en çok kullanılan deneysel yöntemlerdir.4,31

2.1. Prepulse inhibisyon: İrkilme refleksinin zayıf bir ön uyarı aracılığı ile inhibisyonu şizofrenik hayvan modeli çalışmalarında günümüzde kullanılan en önemli yöntemdir. Şizofreni hastalarında da ölçülebilen bir parametre olması önemini arttırmaktadır. Ölçümler Şekil 1'de görülen irkilme refleksi ölçüm cihazı aracılığı ile yapılır. Bu cihaz ses yalıtımlı bir kafesin içinde piyezoelektrik algılayıcılar üzerine yerleştirilmiş özel sıçan kafesleri ve geniş ses aralığına sahip hoparlörlerden ve bir bilgisayardan oluşur. PPI irkilmenin plastisitesidir. Modelin esası irkilme refleksini uyaran sesli (akustik) veya dokunsal (taktil) bir uyarı (pulse) verilmeden önce deney hayvanına zayıf bir uyarı verilmesine (prepulse) ve daha sonra asıl uyarıya deney hayvanının yeterli bir irkilme refleksi ile karşıllk verip veremediğinin ölçülmesine dayanır. Sağlıklı deneklerde daha zayıf bir uyarı şeklinde ön uyaran verildiğinde asıl uyarıya verilen irkilme reflekse verilen cevap azalır (Şekil 2). Şizofreni hastalarında daha zayıf bir ön uyarıyı izleyerek verilen asıl uyarıya karşı 
olușan irkilme refleksinin șiddeti zayıflamaz. Aynı şiddettedir veya daha da şiddetli bir irkilme cevabı ortaya çıkar. ${ }^{12,32}$

Şizofrenik hastalardaki klinik gözlemler, anlamsız düşünceleri otomatik olarak süzmede veya kapılamada yetersizliğe bağlı olarak bilginin işlenmesinde bozukluklar olduğunu göstermiştir. Şizofrenik bozuklukların oluşumundaki teorilerin çoğu, normal insanların dışarıdan aldıkları duyusal uyaranları süzme veya kapılama işlemlerinde yetersizlikler olduğu fenomenine dayanmaktadır. ${ }^{33}$ PPI, beynin normal bir fizyolojik fonksiyonu olan, kortikal ve limbik yapıların birlikte görev aldığı duyusal motor süzme fonksiyonunu gösteren önemli bir belirteçtir. ${ }^{34}$ Başta şizofreni olmak üzere bipolar bozukluk, Huntington Hastalığı, Tourette Sendromu ve obsesif-kompulsif bozukluk gibi birçok psikiyatrik hastalıkta söz konusu inhibisyonun bozulduğu gösterilmiştir. ${ }^{35,36}$
Bir çalıșmada, sıçan hipokampal nöronlarında glutamaterjik NMDA reseptörlerini bloke ederek şizofreninin patogenezinde katkısı olabileceği düşünülen agmatinin ve dopamin agonisti olan apomorfin uygulanarak PPI testi yapılmıştır. Agmatinin PPI üzerine bozucu etkisini değiștirmezken, apomorfin bu etkiyi terse çevirmiştir. Bu iki ilacın birlikte uygulanması sonucu ise PPI anlamlı bir şekilde bozulmuştur. ${ }^{37}$

NMDA reseptör antagonisti olarak MK-801'in gruplara etkisini araştırmak için, 78 dB'deki PPI değerlerine göre düșükten yükseğe doğru sıralanarak "düșük inhibisyonlu" ve "yüksek inhibisyonlu" gruplar oluşturulmuştur. Düşük inhibisyonlu grupta her üç ön uyaranda herhangi bir anlamlı etki oluşturmazken, yüksek inhibisyonlu grupta her üç ön uyaran şiddetinde ve bunların ortalamasında anlamlı olarak PPI bozulmuștur. ${ }^{38}$

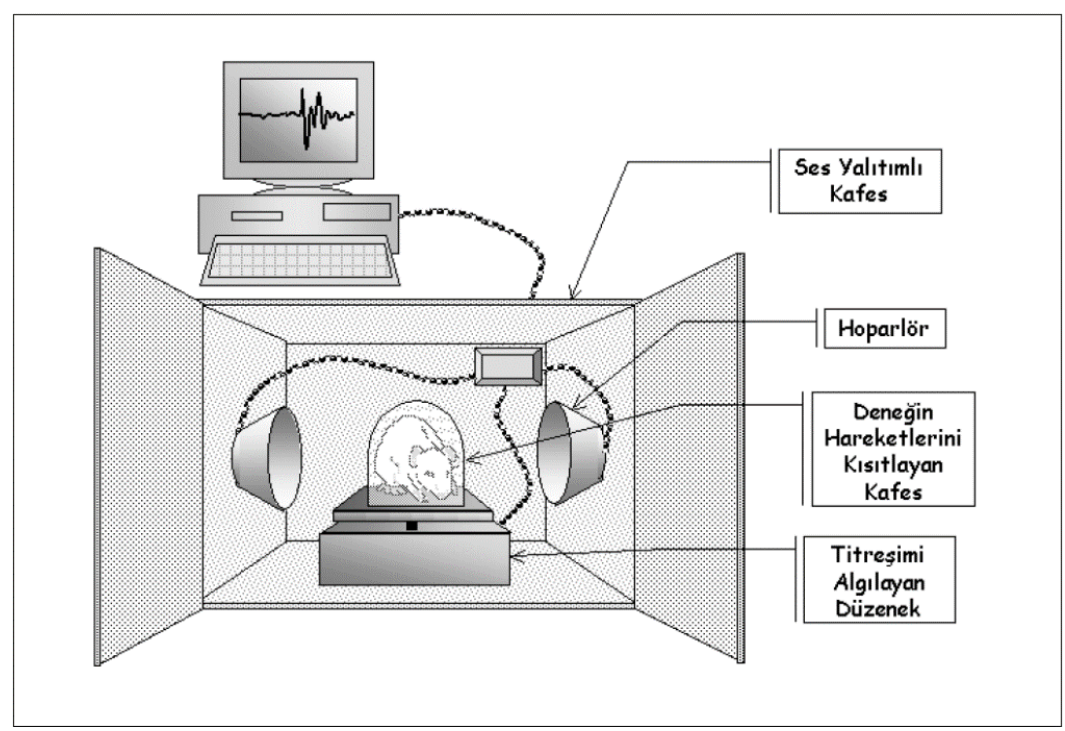

Şekil 1. İrkilme refleksi ölçüm cihazı ${ }^{28}$

Şizofreni hastalarında PPI' deki bozulmanın dikkatte dağınıklık ve düşünce bozukluğu ile korelasyon gösterdiği bulunmuştur. Anokhin ve ark.'nın ${ }^{39}$ yaptığ 1 ikiz çalışmasında kalıtsallığı \%50'nin üzerinde gösterilen PPI 'nin 22q11 delesyonlu bireylerde azalması, aynı zamanda bu bireylerde șizofreni görülme riskinin artmış olması, bu delesyonda etkilenen genlerin şizofrenideki azalmış PPI' den sorumlu olabileceği ihtimalini kuvvetlendirdiği düşünülmüștür. 


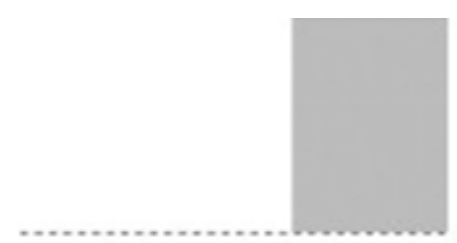

Uyaran

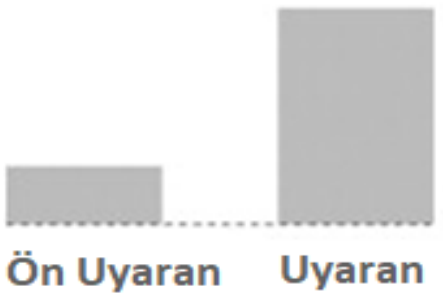

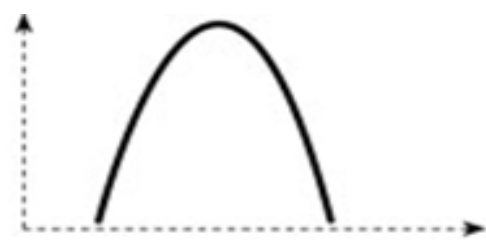

Yanıt

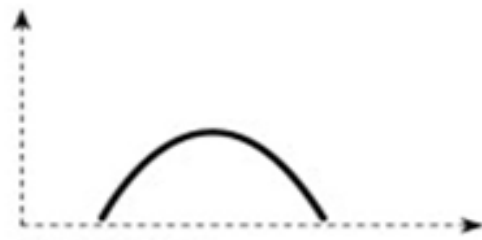

Yanıt

Şekil 2. Ön uyaran aracılı inhibisyonun şekilsel gösterimi

2.2. Yeni obje tanıma testi: Sıçanların da diğer hayvanlar gibi yeni nesneleri ve yerleri keşfetmek için doğuştan bir isteği vardır. Şizofreni de görsel öğrenme ve hafıza zayıflı̆̆ını ölçmek için kullanılan bu test, yeni ve aşina objelerin spontan keşfine dayanır. Ayrıca, Yeni Obje Tanıma Testi performansı büyük oranda kullanılan cisimlere bağlıdır. ${ }^{40}$

Deney ortamına yeni konulan bir objeden daha önce aşina olduğu bir objenin ayrımı sıçan tarafından yapılması beklenir. Deney süresince sıçanın yeni obje etrafında daha fazla zaman geçirdiği görülür. Yeni objenin yanı sıra yeni alan olarak bakıldığında sıçanlar yeni çevreye ilk girdiklerinde, alanın kuytu kısımlarında ya da duvar kenarları boyunca ilerleyip onlar için korunmasız olan alanı tanımak üzere çevrede bulunan nesneleri ve potansiyel tehlikeleri araştırmaya başlarlar. Araştırma davranışları olarak sıçanlar; iki ayağı üzerine kalkma (vertikal aktivite), tırmanma, havayı koklama, süslenme gibi davranışlar sergilerler. Yeni bir çevreye giren sıçanlar yemek yemede isteksizleşirler ve yemeği yemeleri için geçen süre uzamaktadır. ${ }^{41}$

Ketaminin, yeni obje tanıma testinde neden olduğu bozuklukları ölçmek için yapılan bir çalışmada, test uygulanmadan önce sıçanın alana beş dakika ile 24 saat arasında alışması sağlanmıştır. Şekil 3a'da görüldüğü gibi, iki dakikalık denemeler içeren testte, birinci deneme sırasında iki özdeş cisim karşıt köşelere konmuştur. İkinci deneme de ise objenin biri yeni bir objeyle değiştirilmiştir. Sıçanlar yeni konan objeyi koklayarak, yalayarak nesnenin üzerinde oturarak ya da karşısında dikilerek tanımaya çalışmışlardır. Sıçanların bu davranışları alanın üzerine konumlandırılmış bir kamera ile kayıt altına alınmıştır. Ketamin uygulanan gruptaki sıçanlarda yeni ve aşina objeyi ayırt etme yeteneği ortadan kalkmıștır. ${ }^{42}$
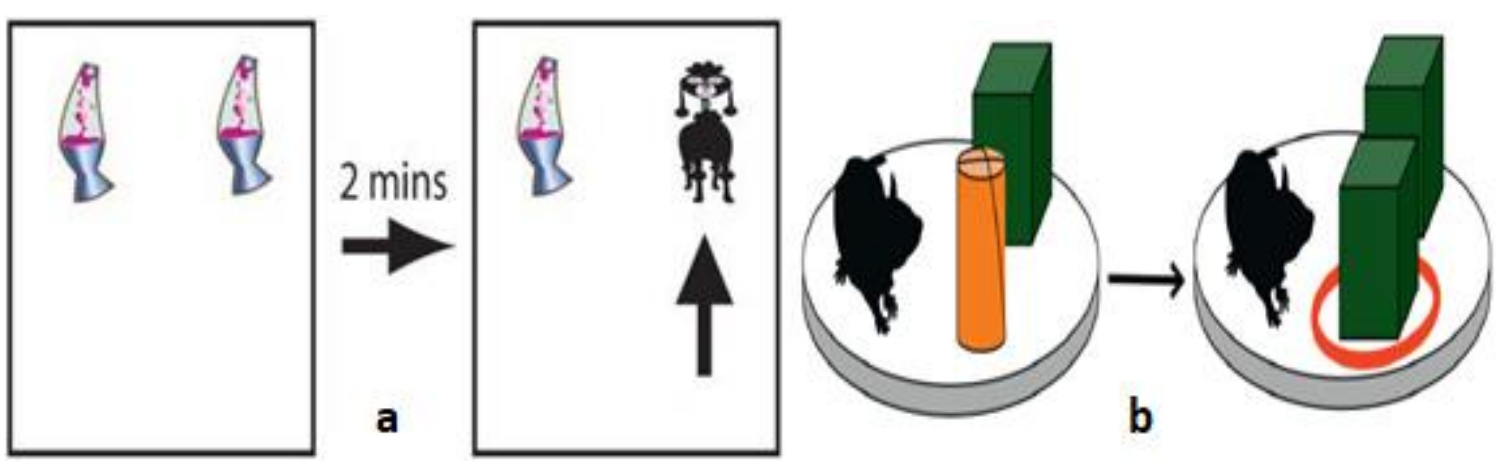

Şekil 3. Yeni obje tanıma testi 42,43 
Başka bir çalıșmada ise başlangıçta silindir ve küp şeklinde iki farklı nesne alana koyulmuştur (Şekil 3b). Sıçanın bulunduğu ortamda toplam iki dakika, her iki farklı nesne etrafında eşit zaman geçirmiştir. Daha sonra silindir şekilde olan nesne ortamdan alınmış ve yerine ortamdaki nesnenin aynısı (küp) koyulmuştur. Sıçanın ilgisi ortamda olan küpe değil, yeni konulan küpe olmuştur. ${ }^{43}$

Cariprazine and aripiprazole ilaçlarının yeni obje tanıma üzerine etkisi ölçülen çalışmada Şekil 3b' deki örneğe benzer düzenek olușturulmuștur. Her iki ilaç araştırmasında da sıçanlar, seçim denemesinde yeni obje ile önceden görmüș olduğu objeyi ayırt edemediği görülmüştür. ${ }^{44}$

\section{Sonuç ve öneriler}

İnsanlar üzerinde modellenmesi zor olan şizofreni gibi nörofizyolojik bozuklukların gelecekte prenatal dönemde engellenebilmesi açısından deney hayvanı modellerinin derinleştirilmesi gerekmektedir. Genetik, gelişimsel ve kimyasal modellerle oluşturulan bu hastalığın temellerini kavrayabilmek ve yeni tedaviler geliştirebilmek için özellikle PPI testi ve yeni obje tanıma testinin deney hayvanı modellerinde geliștirilmesi ve daha geniş çaplı çalışmalarda kullanılması sonucuna varılmıștır.

\section{Kaynakça}

1. Tamminga CA, Holcomb HH. Phenotype of schizophrenia: A review and formulation. Mol Psychiatry 2005;10:27-39.

2. Ross CA, Margolis RL, Reading SA, Pletnikov M, Coyle JT. Neurobiology of schizophrenia. Neuron 2006;1:139-153.

3. World Health Organization Schizophrenia 2016. Erişim yeri: https://www.who.int/mental health/mana gement/schizophrenia/en, Erişim tarihi: 03.01.2019.

4. Göktalay G, Aktaş Ö, Kayır H. Türkiye Klinikleri J Pharmacol-Special Topics. 2016;4:53-60.
5. Hay A, Byers A, Sereno M, Basra MK, Dutta S. Asenapine versus placebo for schizophrenia. Cochrane Database Syst Rev. 2015;24.

6. Perry W, Geyer MA, Braff DL. Sensorimotor gating and thought disturbance measured in close temporal proximity in schizophrenic patients. Arch Gen Psychiatry. 1999;56:277-281.

7. Ural C, Öncü F, Belli H, Soysal H. Adli psikiyatrik süreç içindeki şizofreni hastalarının şiddet davranışı değișkenleri: Bir olgu kontrol çalışması. Türk Psikiyatri Dergisi. 2013;24:17-24.

8. Mouri A, Nagai T, Ibi D, Yamada K. Animal models of schizophrenia for molecular and pharmacological intervention and potential candidate molecules. Neurobiol Dis.2013;53:61-74.

9. Farrell MS, Werge T, Sklar P, Owen MJ, Ophoff RA, O'Donovan MC at al. Evaluating historical candidate genes for schizophrenia. Mol Psychiatry. 2015;1-8.

10. Negron-Oyarzo et al. Schizophrenia and reelin: A model based on prenatal stress to study epigenetics, brain development and behavior. Biol Res. 2016;49:16.

11. Rusnak F, Mertz P. Calcineurin: Form and function. Physiol Rev. 2000;80:14831521.

12. Miyakawa T, Leiter LM, Gerber DJ, Gainetdinov RR, Sotnikova TD, Zeng H, Caron MG, Tonegawa S. Conditional calcineurin knockout mice exhibit multiple abnormal behaviors related to schizophrenia. Proc Natl Acad Sci USA. 2003;100:8987-8992.

13. Stefansson H, Steinthorsdottir V, Thorgeirsson TE, Gulcher JR, Stefansson K. Neuregulin 1 and schizophrenia. Ann Med. 2004;36:62-71.

14. Le Strat Y, Ramoz N, Gorwood P. The role of genes involved in neuroplasticity and neurogenesis in the observation of a gene-environment interaction (GxE) in schizophrenia. Current Molecular Medicine. 2009;4:506-518.

15. Williams N, O'Donovan M, Owen M. Is the dysbindin gene (DTNBP1) a 
susceptibility gene for schizophrenia? Schizophr Bull. 2005;31:800-805.

16. Talbot K, Eidem WL, Tinsley CL, Benson MA, Thompson EW, Smith RJ, et al. Dysbindin-1 is reduced in intrinsic, glutamatergic terminals of the hippocampal formation in schizophrenia. The Journal of clinical investigation.2004;113:1353-1363.

17. Weickert CS, Straub RE, McClintock BW, Matsumoto M, Hashimoto R, Hyde TM, et al. Human dysbindin (DTNBP1) gene expression in normal brain and in schizophrenic prefrontal cortex and midbrain. Archives of general psychiatry. 2004;61:544-555.

18. Brown AS. Prenatal infection as a risk factor for schizophrenia. Schizophr Bull. 2006;32:200-202.

19. Dong E, Dzitoyeva SG, Matrisciano F, Tueting P, Grayson DR, Guidotti A. Brainderived neurotrophic factor epigenetic modifications associated with schizophrenia-like phenotype induced by prenatal stress in mice. Biol Psychiatry. 2015;77:589-596.

20. Ahmed AO, Mantini AM, Fridberg DJ, Buckley PF. Brain-derived neurotrophic factor (BDNF) and neurocognitive deficits in people with schizophrenia: A meta-analysis. Psychiatry Res. 2015;226:1-13.

21. Scarr E, Beneyto M, Meador-Woodruff JH, Dean B. Cortical glutamatergic markers in

Neuropsychopharmacology. schizophrenia. 2005;30:1521-1531.

22. Luby ED, Cohen BD, Rosenbaum G, Gottlieb JS, Kelley R. Study of a new schizophrenomimetic drug; sernyl. $A M A$ Arch Neurol Psychiatry. 1959;81:363369.

23. Carlsson M, Carlsson A. Schizophrenia: A subcortical neurotransmitter imbalance syndrome? Schizophr Bull 1990;16:425432.

24. Robinson TE, Becker JB. Enduring changes in brain and behavior produced by chronic amphetamine administration: A review and evaluation of animal models of amphetamine psychosis. Brain Res. 1986;396:157-198.

25. Geyer MA, Krebs-Thomson K, Braff DL, Swerdlow NR. Pharmacological studies of prepulse inhibition models of sensorimotor gating deficits in schizophrenia: A decade in review. Psychopharmacology (Berl). 2001;156(23):117-154.

26. Geyer MA, Braff DL, Swerdlow NR. Startle-response measures of information processing in animals: Relevance to schizophrenia. In: Haug M, Whalen RE, eds. Animal models of human emotion and cognition. Washington, DC: APA Books. 1999:103-116.

27. Swerdlow NR, Geyer MA. Using an animal model of deficient sensorimotor gating to study the pathophysiology and new treatments of schizophrenia. Schizophr Bull.1998;24:285-301.

28. Uzbay T. Şizofreni tedavisinde yeni farmakolojik yaklaşımlar. Turk Psikiyatri Derg. 2009;20:175-182.

29. Uslu G, Savci V, Buyukuysal LR, Goktalay G. CDP-choline attenuates scopolamine induced disruption of prepulse inhibition in rats: İnvolvement of central nicotinic mechanism. Neurosci Lett. 2014;569:153-157.

30. Sams-Dodd F, Lipska BK, Weinberger DR. Neonatal lesions of the rat ventral hippocampus result in hyperlocomotion and deficits in social behaviour in adulthood. Psychopharmacology (Berl). 1997;132:303-310.

31. Cadinu D, Grayson B, Podda G, Harte MK, Doostdar N, Neill JC. NMDA receptor antagonist rodent models for cognition in schizophrenia and identification of novel drug treatments, an update. Neuropharmacology. 2018;142:41-62.

32. Braff DL, Geyer MA, Swerdlow NR. Human studies of prepulse inhibition of startle: normal subjects, patient groups, and pharmacological studies. Psychopharmacology (Berl). 2001;156:234-258.

33. Geyer MA, Krebs-Thomson K, Braff DL, Swerdlow NR. Pharmacological studies 
of prepulse inhibition models of sensorimotor gating deficits in schizophrenia: A decade in review. Psychopharmacology. $\quad 2001 ; 156: 117-$ 154.

34. Braff DL, Geyer MA. Sensorimotor gating and schizophrenia: human and animal model studies. Arch Gen Psychiatry. 1990;47:181-188.

35. Swerdlow NR, Paulsen J, Braff DL, Butters $\mathrm{N}$, Geyer MA, Swenson MR. Impaired prepulse inhibition of acoustic and tactile startle response in patients with Huntington's disease. J Neurol Neurosurg Psychiatry. 1995;58:192-200.

36. Castellanos FX, Fine EJ, Kaysen D, Marsh WL, Rapoport JL,Hallet M. Sensorimotor gating in boys with Tourette's syndrome and ADHD:preliminary results. Biol Psychiatry. 1996;39:33-41.

37. Uzbay T, Kayir H, Goktalay G, Yildirim M. Agmatine disrupts prepulse inhibition of acoustic startle reflex in rats. $J$ Psychopharmacol. 2010; 24:923-929.

38. Yee BK, Chang DL, Feldon J. The Effects of dizocilpine and phencyclidine on prepulse inhibition of the acoustic startle reflex and on prepulse-elicited reactivity in C57BL6 mice. Neuropsychopharmacology. 2004;29:1865-1877.

39. Anokhin AP, Heath AC, Myers E at al. Genetic influences on prepulse inhibition of startle reflex in humans. Neurosci Lett. 2003;353:45-48.
40. Li SJ, Huang ZY, Ye YL, Yu YP, Zhang WP, Wei EQ, Zhang Q. Influence of object material and inter-trial interval on novel object recognition test in mice. Zhejiang Da Xue Xue Bao Yi Xue Ban. J. Zhejiang Univ. Med. Sci. 2014;43,346-352.

41. Barnett SA. 1963 The rat-a study in behavior (AldineTransaction, A division of Transaction Publishers, Rutgers - The State University, New Jersey).

42. Nikiforuk A, Kos T, Hołuj M, Potasiewicz A, Popik P. Positive allosteric modulators of alpha 7 nicotinic acetylcholine receptors reverse ketamine-induced schizophrenia-like deficits in rats. Neuropharmacology. 2016;101:389-400.

43. Albani SH, McHail DG, Dumas TC. Developmental studies of the hippocampus and hippocampaldependent behaviors: İnsights from interdisciplinary studies and tips for new investigators. Neurosci Biobehav Rev. 2014;43:183-190.

44. Watson DJ, King MV, Gyertyán I, Kiss B, Adham N, Fone KC. The dopamine $\mathrm{D}_{3}$ preferring $D_{2} / D_{3}$ dopamine receptor partial agonist, cariprazine, reverses behavioural changes in a rat neurodevelopmental model for schizophrenia. Eur Neuropsychopharmacol. 2016;26:208224. 